\title{
Insects with Potential Medicinal Significance: A Review
}

\author{
Shriram H Bairagi* \\ Assistant Professor, Dept of Pharmaceutical Chemistry, India \\ *Corresponding author: Shriram H Bairagi, Assistant Professor, Dept of Pharmaceutical Chemistry, Ideal College of Pharmacy and \\ Research, Mumbai, India 421306
}

\section{ARTICLE INFO}

Received: 幽 March 18, 2019

Published: March 26, 2019

Citation: Shriram H Bairagi. Insects with Potential Medicinal Significance: A Review. Biomed J Sci \& Tech Res 16(3)-2019. BJSTR. MS.ID.002849.

Keywords: Insects; Anti-HIV; Antibacterial activity
ABSTRACT

In ancient cultures, insects were used as medicine, and today, scientists are studying and trying to rediscover many natural products from insects. Insects and insect-derived products are used in many parts of the world since ancient times as medicinal agents. The medicinal uses of insects and other arthropods plays an important role to treat various maladies and injuries and has a long tradition can be effective and provide results. Insect as a natural product having potential source as a medicine that is useful in curing as well as giving protection from some major diseases such as Bacterial infections, HIV and Cancer etc.

\section{Introduction}

Pest Control means management or elimination of insects, wildlife, \& rodents that have become pests of humans. In ancient cultures, insects were used as medicine, and today, scientists are studying and trying to rediscover many natural products from insects. Insects and insect-derived products are used in many parts of the world since ancient times as medicinal agents. Honey is applied to treat burns. Honey and beeswax combination used for several dermatologic disorders, includes psoriasis, tinea, pityriasis versicolor, atopic dermatitis and diaper dermatitis. Royal jelly used to treat postmenopausal symptoms. Bee and ant venom have reduced the number of swollen joints in patients with rheumatoid arthritis. Propolis, a hive sealant made by bees, has been utilized to cure aphthous stomatitis. Cantharidin, a derivative of the bodies of blister beetles, has been applied to treat warts and molluscum contagiosum. Combining insects with conventional treatments may provide further benefit. The medicinal uses of insects and other arthropods plays an important role to treat various maladies and injuries and has a long tradition can be effective and provide results [1]. Insects and other arthropods provide ingredients that have been a staple of traditional medicine for centuries in part of East Asia, Africa and South America.

\section{Honey Bee Products Used as Medicine}

To treat diseases, such as arthritis, rheumatism, pain, cancerous tumors and skin diseases Bee venom therapy have been used in traditional medicine. Bee venom contains a variety of peptides including melittin, apamin, ado lapin, the mast cell degranulating peptide, enzymes (phospolipase-A2), and amines like histamine and epinephrine and nonpeptide components with a variety of pharmaceutical properties. For the treatment of cancer cells, including renal, lung, liver, prostate, mammary gland as well as leukemia cells can be targets of bee venom peptides such as melittin and phospolipase-A2. Recently Moon et.al reported that bee venom can induce apoptosis in cancer cells (in human leukemic U937cells) the key regulators in bee venom induced apoptosis are Bcl-2 and caspase- 3 through down regulation of the ERK and Akt signal pathway [2].

\section{Treatment for Rheumatoid Arthritis}

Bee venom induces apoptosis in rheumatoid synovial cells through a decrease in BCL2 expression and an increase in BAX and caspase- 3 expression. Bee venom induces apoptosis through caspase-3 activation in synovial fibroblasts of patients with rheumatoid arthritis [3].

\section{Treatment for HIV}

Toxin found in bee venom can destroy Human immunodeficiency virus (HIV). Bee venom contains melittin that surrounds HIV virus as well as other viruses. This melittin is loaded with nanoparticles that attack an essential part of the virus' structure. Nanoparticles 
are easy to manufacture in large quantities to supply them for future clinical trials [4]

\section{Maggot Products}

Maggot therapy is a type of biotherapy involves the introduction of live, disinfected maggots (fly larvae) into the nonhealing skin and soft tissue wound(s) of a human or animal for the purpose of cleaning out the necrotic (dead) tissue within a wound (debridement) and disinfection. There is evidence that maggot therapy may help with wound healing [5]. Maggot therapy divided into 3 processes:
a) debridement of wounds;
b) wound healing;
c) disinfection of wounds.

Debridement of Wounds: Application of maggots to the wound then cleaning and removal of necrotic tissue and debris (eschar) occur so that granulation and healing can begin. Maggots clean wounds by the extra- corporeal production of enzymes that digest the debris which the maggots then feed upon [6]. initially, the main enzymes identified in the maggot excretions/secretion (ES) is chymotrypsin and trypsin-like serine proteases, an aspartyl proteinase and a metalloproteinase. Ammonia secretion increases the $\mathrm{pH}$ to activate the serine proteases. The most active enzymes are produced by first instar larvae [7]. Wound Healing: It has an immunomodulatory role in the wound healing process 8 In particular, neutrophils, macrophages, lymphocytes, and the complement system respond to exposure to the MS. With neutrophils, the ES inhibit elastase, the respiratory burst, hydrogen peroxide production, and migration of these cells.

Elastase breaks down the extracellular matrix and delays epithelial repair, while oxygen radicals would probably have a similar effect. Concomitantly, the inhibition of neutrophil migration would help resolve the prolonged inflammatory response, to which they contribute, present in a chronic [8,9]. Disinfection of Wounds: ES able to kill bacterial infection of wounds, including antibioticresistant strains such as MRSA [10]. Many different antibacterial factors in dipterans, includes a range of AMPs such as Sarcotoxin$1 \mathrm{~A}$, a cecropin-like molecule from the flesh fly Sarcophaga peregrine, which is more active against Gram-negative bacteria than Grampositive forms [11]. More recently lucifensin II was discovered and characterized from Lucilia cuprina and found to be identical to the L. sercata lucifensin except for one amino acid residue Thus, lucigenin's are cationic AMP (antimicrobial peptide) has main activity against Gram-positive bacteria [12]. The anti-bacterial factors of the house fly, Musca domestica are also detected, because of its role as a vector of pathogens such as MRSA [13,14].

\section{Fruit Fly}

Fruit fly is the type of insect which can detect one of the treacherous diseases which we called "cancer". Cancer cells exhibit a metabolism that is fundamentally altered as compared to that of normal cells $[15,16]$ leading to changes in the tumor's microenvironment, in lipid peroxidation activity and to a variety of potential intra-and extracellular cancer-specific markers. Thus, quantitative and qualitative variations of metabolites provide important information on cell condition $[17,18]$.

\section{Ant}

The South American tree ant, Pseudomyrmex sp. commonly called as the samsum ant has venom which possesses many pharmacological effects such as reducing inflammation, relieving pain, inhibition of tumor growth, hepatitis treatment, and liver protection [19]. According to Bai, a primary alkaloid obtained from fire ant Solenopsis invicta exhibits anti angiogenic activity; this toxin has the ability to inhibit a series of kinases involving in angiogenesis mechanism. Polyrachisla mellidens, a medicinal ant used in Chinese medicine, was confirmed to exert potent analgesic and anti-inflammatory actions [20]. Its therapeutic efficacy in the treatment of various inflammatory disorders had been reported [21]. Weak vision was treated with ant eggs mixed with an equal amount of white flour to make dough [22]. Most of the native healers used ants. Ants were put into canvas bags and put around the legs of paralyzed [23].

\section{Termite}

From a serviceable standpoint, termites are commonly used insects in traditional popular medicine [24-27]. A total of 45 termite species belonging to four families were recorded as being used by human populations, with 43 species used in the human diet or for livestock feeding and nine species used as a therapeutic resource [28]. Different species of termites are used to treat various diseases that affect human's health. For e.g. Microkeratomes exiguous used for asthma, bronchitis, influenza, whooping cough, flu. Nasturtiums macrocephalus is used to treat asthma, leakage, bronchitis, 'catarrh in the chest' coughs, influenza, sore throat, sinusitis and tonsillitis [29] (Figure 1) (Table 1).

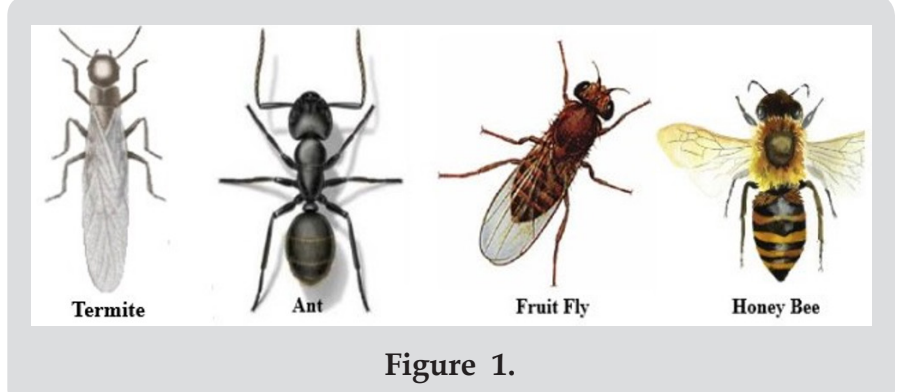


Table 1: Insects as medicines in different human cultures.

\begin{tabular}{|c|c|c|}
\hline \multicolumn{3}{|c|}{ Insects as medicines in different human cultures } \\
\hline Common Name & Scientific Name & Disease Treated \\
\hline Locust & - & Post childbirth anemia, lung diseases, e.g, asthma and chronic cough \\
\hline Pod Borer Weevil & Helicoverpa armigera & Panacea Stomach Pains \\
\hline May Beetle & Melolontha vulgaris & Scratches, anemia, rheumatism \\
\hline House Fly & Musca domestica & Eye cysts, baldness \\
\hline Cicada & Huechys sanguinea & Migraine headache, ear infection \\
\hline Red velvet mite & Trombidium grandissimum & Malaria, urogenital disorders, paralysis, aphrodisiac \\
\hline Cattle tick & Boophilus microplus & Chickenpox \\
\hline Ground beetle & Scarites spp. & Suture wounds \\
\hline Peanut beetle & Palenmbus dermestoides & Asthma, arthritis, tuberculosis, sexual importence \\
\hline Ghost moth & Hepialus oblifurcus & Fortifier \\
\hline Giant skipper & Aegiale hesperiaris & Rheumatism, aphrodisiac \\
\hline Palm beetle & Pachymerus nucleorum & Earache \\
\hline Mud wasps & Synagris spp. And Sceliphron spp & Provide lime to the fetus \\
\hline Stingless bee & Trigona spinipes & Cough, Acne \\
\hline
\end{tabular}

\section{Conclusion}

The purpose of the present study is to focus on the use of insect as a natural product having potential source as a medicine that is useful in curing as well as giving protection from the diseases. Here are the significant recent advances in developing insect as potential new alternative medicinal drugs. This is an exciting and rapidly expanding new field since insects are hugely variable and have utilized an enormous range of natural products to cope up the environmental perturbations for many years.

\section{References}

1. Meyer Rochow VB (2017) Therapeutic arthropods and other, largely terrestrial, folk- medicinally important invertebrates: a comparative survey and review. Journal of Ethnobiology and Ethnomedicine 13(1): 9.

2. Moon DO, Park SY, Heo MS, Kim KC, Park C, et al. (2006) Key regulators in bee venom induced apoptosis are Bcl-2 and caspase-3 in human leukemic U937 cells through down regulation of ERK and Akt. International Immunopharmacology 6(12): 1796-1807.

3. Hong SJ, Rim GS, Yang HI, Yin CS, Koh HG, et al. (2005) Bee venom induces apoptosis through caspase-3 activation in synovial fibroblasts of patients with rheumatoid arthritis. Toxicon 46(1): 39-45.

4. Hood JL, Jallouck AP, Campbell N, Ratner L, Wickline SA (2013) Cytolytic nanoparticles attenuate HIV-1 infectivity. Antiviral Therapy 18(1): 95103.

5. Sherman RA, Pechter EA (1988) Maggot therapy: a review of the therapeutic applications of fly larvae in human medicine, especially for treating osteomyelitis. Med Vet Entomol 2(3): 225-230.

6. Ratcliffe NA, Mello CB, Garcia ES, Butt TM, Azam-buja P (2011) Molecular Biology 41(10): 747-769.

7. Chambers L, Woodrow S, Brown AP, Harris PD, Phillips D, et al. (2003) Degradation of extra cellular matrix components by defined proteinases from the green bottle larva Lucilia sericata used for the clinical debridement of non-healing wounds. British Journal of Dermatology 148(1): 14-23.
8. Bohova J, Majtan J, Takac P (2012) Immunomodulatory properties of medicinal maggots Lucilia sericata in wound healing process. TANG International Journal of Genuine Traditional Medicine 2(3): 1-7.

9. Van der Plas MJA, van der Does AM, Baldry M, Dogterom Ballering HC van Gulpen C, et al. (2007) Maggot excretions/secretions inhibit multiple neutrophil proinflammatory responses, Microbes and Infection 9(4): 507-514.

10. Ratcliffe NA, Mello CB, Garcia ES, Butt TM, Azam buja P (2011) Insect natural products and processes: new treatments for human disease. Insect Biochemistry and Molecular Biology 41(10): 747-769.

11. Natori S (2010) Molecules participating in insect immunity of Sarcophaga peregrine. Proceedings of the Japan Academy Series B: Physical and Biological Sciences 86(10): 927-938.

12. Andersen AS, Sandvang D, Schnorr KM, Thomas Kruse, Søren Neve, et al. (2010) A novel approach to the antimicrobial activity of maggot debridement therapy. Journal of Antimicrobial Chemotherapy 65(8): 1646-1654.

13. Joyner C, Mills MK, Nayduch D (2013) Pseudomonas aeruginosa in Musca domestica L.: temporospatial examination of bacteria population dynamics and house fly antimicrobial responses. PLoS ONE 8(11): e79224.

14. Park SO, Shin JH, Choi WK, Park BS, Oh JS, et al. (2010) Antibacterial activity of housefly-maggot extracts against MRSA (Methicillin-resistant Staphylococcus aureus) and VRE (Vancomycin-resistant enterococci). Journal of Environmental Biology 31(5): 865-871.

15. Tennant, DA, Duran, RV, Gottlieb E (2010) Targeting metabolic transformation for cancer therapy. Nat Rev Cancer 10(4): 267-277.

16. Ward PS, Thompson CB (2012) Metabolic reprogramming: A cancer hallmark even Warburg did not anticipate. Cancer Cell 21(3): 297-308.

17. Singer SJ, Nicolson GL (1972) The fluid mosaic model of the structure of cell membranes. Science 175(4023): 720-731.

18. Kneepkens CM, Lepage G, Roy CC (1994) The potential of the hydrocarbon breath test as a measure of lipid peroxidation. Free Radical Biol Med 17(2): 127-160.

19. Altman RD, Schultz DR (1984) The effect of a partially purified fraction of ant venom in rheumatoid arthritis. Arthritis Rheum 27(3): 277-284. 
20. Bai X, Cerimele F, Ushio Fukai M, Waqas M, Campbell P M, et al. (2003) Honokiol a small molecular weight natural product inhibits angiogenesis in vitro and tumor growth in vivo. J Biol Chem 278(37): 35501-35507.

21. Kou J, Ni Y, Li N, Wang J, Liu L et al. (2005) Analgesic and anti-inflammatory activities of total extract and individual fractions of Chinese medicinal ants Polyrhachis lamellidens. Biol Pharm Bull 28(1): 176-180.

22. Gudger EW (1925) Stitching wounds with the mandibles of ants and beetles. Journal of the American Medical Association 84(24): 1861-1864.

23. Attygalle AB (1989) Chemical composition and function of metapleural gland secretion of the Ant, Crematogaster deformis. Journal of Chemical Ecology 15: 317-328.

24. Alves RRN, Alves HN (2011) The faunal drugstore: Animal-based remedies used in traditional medicines in Latin America. J Ethnobiol Ethnomed 7: 9

25. Solavan A, Paulmurugan R, Wilsanand V (2006) Effect of the subterranean termite used in the South Indian folk medicine. Indian J Tradit Knowl. 5: 376-379.

\section{ISSN: 2574-1241}

DOI: 10.26717/BJSTR.2019.16.002849

Shriram H Bairagi. Biomed J Sci \& Tech Res

(C) This work is licensed under Creative

Submission Link: https://biomedres.us/submit-manuscript.php
26. Coutinho HDM, Vasconcellos A, Lima MA, Almeida- Filho GG, Alves RRN (2009) Termite usage associated with antibiotic therapy: enhancement of aminoglycoside antibiotic activityby natural products of Nasutitermes corniger (Motschulsky 1855). BMC Complement Altern Med 9: 35.

27. Lima JRB, Santos CAB (2010) Recursos Animais Utilizados na medicina Tradicional dos Índios Pankararu no Nordeste do Estado de Pernambuco, Brasil. Etnobiologia 8(1): 39-50.

28. Figueirêdo R E C R de, Alexandre V, Iamara SP and Alves RN (2015) Edible and medicinal termites: a global overview. Journal of Ethnobiology and Ethnomedicine 11: 29.

29. Alves RN, Alves HN (2011) The faunal drugstore: Animal-based remedies used in traditional medicines in Latin America. J Ethnobiol Ethnomed 7: 9.

$\begin{array}{ll}\text { BIOMEDICAL } & \text { Assets of Publishing with us } \\ \text { RESEARCHES } & \text { - Global archiving of articles } \\ & \text { - Immediate, unrestricted online access } \\ & \text { - Rigorous Peer Review Process } \\ & \text { - Authors Retain Copyrights }\end{array}$

